\title{
METHYLATION OF POSITION 8 IN THE PYRIDINE MOIETY OF THE $N$-(BENZYL)-2-HYDROXY-4-OXO-4H-PYRIDO [1,2-a]PYRIMIDINE-3-CARBOXAMIDE MOLECULE AS AN ATTEMPT TO ENHANCE THEIR ANALGESIC PROPERTIES
}

\author{
I.V.Ukrainets, O.V.Gorokhova, L.V.Sydorenko, S.G.Taran \\ National University of Pharmacy, Kharkiv, Ukraine \\ 53, Pushkinska Str., Kharkiv, 61002.E-mail: uiv-2@mail.ru
}

Key words: amidation; tricarbonylmethane heterocyclic derivatives; 2-hydroxy-4-oxo-4H-pyrido[1,2-a]

pyrimidine-3-carboxamides; synthesis; chemical modification; analgesic activity

\begin{abstract}
The chemical modification of the pyridine moiety of the molecule - displacement of the methyl group in position 8 of pyrido[1,2-a]pyrimidine nucleus has been considered as one of the possible versions to optimize the biological properties of $\mathrm{N}$-(benzyl)-2-hydroxy-4-oxo-4H-pyrido[1,2-a]pyrimidine-3-carboxamides. The synthesis of the research targets was carried out by the reaction of the corresponding benzylamines and ethyl 2-hydroxy-8-methyl-4-oxo-4H-pyrido[1,2-a] pyrimidine-3-carboxylate, in its turn obtained by condensation of 2-amino-4-methylpyridine (i.e. the product with the methyl group in the intentionally required position) and triethyl methanetricarboxylate. The structure of the compounds obtained has been confirmed by the data of elemental analysis and NMR ${ }^{1} \mathrm{H}$ spectroscopy, and in the case of optically active 1-phenylethylamides additionally by polarimetry. The study of the analgesic properties of all N-(benzyl)-2-hydroxy8-methyl-4-oxo-4H-pyrido[1,2-a]pyrimidine-3-carboxamides was performed on the standard experimental "acetic acid writhing" model. At the same time, it has been found that our modification is accompanied with the increased biological activity of exclusively para-substituted derivatives. For profound research 4-fluorobenzylamide exceeding Piroxicam and Nabumetone by the level of the specific effect has been recommended as a potential new analgesic.
\end{abstract}

МЕТИЛЮВАННЯ ПОЛОЖЕННЯ 8 ПІРИДИНОВОЇ ЧАСТИНИ МОЛЕКУЛИ N-(БЕНЗИЛ)-2-ГІДРОКСИ-4-ОКСО4Н-ПІРИДО[1,2-а]ПІРИМІДИН-3-КАРБОКСАМІДІВ ЯК СПРОБА ПОСИЛЕННЯ ЇХ АНАЛГЕТИЧНИХ ВЛАСТИВОСТЕЙ

І.В.Українець, О.В.Горохова, Л.В.Сидоренко, С.Г.Таран

Ключові слова: амідування; гетероциклічні похідні трикарбонілметану; 2-гідрокси-4-оксо-4Н-піридо[1,2-а] піримідин-3-карбоксаміди; синтез; хімічна модифькація; аналгетична активність

Як один з можливих варіантів оптимізації біологічних властивостей N-(бензил)-2-гідрокси-4-оксо-4Hпіридо[1,2-а]піримідин-3-карбоксамідів розглянуто хімічну модифрікацію піридинової частини їх молекули - переміщення метильної групи у положення 8 піридо[1,2-а]піримідинового ядра. Синтез цільових об'єктів дослідження здійснено реакцією відповідних бензиламінів з етил-2-гідрокси-8-метил-4-оксо-4Hпіридо[1,2-а]піримідин-3-карбоксилатом, у свою чергу, одержаним конденсацією 2-аміно-4-метилпіридину (тобто продукту з метильною групою в завідомо необхідному положенні) з триетилметантрикарбоксилатом. Будову синтезованих речовин підтверджено даними елементного аналізу та спектроскопії ${ }^{1} \mathrm{H}$ ЯМР, а у випадку оптично активних 1-френілетиламідів додатково ще й поляриметрично. Вивчення аналгетичних властивостей усіх N-(бензил)-2-гідрокси-8-метил-4-оксо-4Н-піридо[1,2-а]піримідин-3-карбоксамідів проведено на стандартній експериментальній моделі оцтовокислих корчів. При цьому знайдено, що здійснена нами модифікація супроводжується посиленням біологічної активності виключно паразаміщених похідних. Для поглиблених випробовувань як новий потенційний аналгетик рекомендовано 4-фрторобензиламід, який перевищує за рівнем специфрічного ефректу Піроксикам та Набуметон.

МЕТИЛИРОВАНИЕ ПОЛОЖЕНИЯ 8 ПИРИДИНОВОЙ ЧАСТИ МОЛЕКУЛЫ N-(БЕНЗИЛ)-2-ГИДРОКСИ-4ОКСО-4Н-ПИРИДО[1,2-а]ПИРИМИДИН-З-КАРБОКСАМИДОВ КАК ПОПЫТКА УСИЛЕНИЯ ИХ АНАЛЬГЕТИЧЕСКИХ СВОЙСТВ

И.В.Украчнец, О.В.Горохова, Л.В.Сидоренко, С.Г.Таран

Ключевые слова: амидирование; гетероциклические производные трикарбонилметана; 2-гидрокси-4оксо-4Н-пиридо[1,2-а]пиримидин-3-карбоксамиды; синтез; химическая модификация; анальгетическая активность

В качестве одного из возможных вариантов оптимизации биологических свойств N-(бензил)-2-гидрокси4-оксо-4Н-пиридо[1,2-а]пиримидин-3-карбоксамидов рассмотрена химическая модификация пиридиновой части их молекулы - перемещение метильной группы в положение 8 пиридо[1,2-а]пиримидинового ядра. Синтез целевых объектов исследования осуществлен реакцией соответствующих бензиламинов с этил-2-гидрокси-8-метил-4-оксо-4Н-пиридо[1,2-а]пиримидин-3-карбоксилатом, в свою очередь, полученным конденсацией 2-амино-4-метилпиридина (m. е. продукта с метильной группой в заведомо требуемом положении) с триэтилметантрикарбоксилатом. Строение синтезированных веществ подтверждено данными элементного анализа и спектроскопии ${ }^{1} \mathrm{H}$ ЯМР, а в случае оптически активных 1-фенилэтиламидов дополнительно еще и поляриметрически. Изучение анальгетических свойств всех $N$-(бензил)-2-гидрокси-8-метил-4-оксо-4Н-пиридо[1,2-а]пиримидин-3-карбоксамидов проведено на стандартной экспериментальной модели уксуснокислых корчей. При этом найдено, что предпринятая нами модификация сопровождается усилением биологической активности исключительно паразамещенных производных. Для углубленных испытаний в качестве нового потенциального анальгетика рекомендован 4-фрторбензиламид, превосходящий по уровню специфического эффректа Пироксикам и Набуметон. 
Different versions of the chemical modification of biologically active substances and auxiliary materials used in medicine up to now remain one of the most effective and, most importantly, almost easily feasible methods to improve their pharmacological and/or pharmaceutical properties [1]. This methodology has long been successfully used by medicinal chemists to intensify the specific action $[2,3]$, increase selectivity towards a particular receptor [4-6], improve the thermal stability [7], biocompatibility [8], bioavailability [9], safety [10], correction of taste [11], as well as to solve many other problems [1115] associated with optimization of both the known and newly developed drugs.

Taking into account these data and continuing our extensive research in searching new promising analgesics among amide derivatives of 4-hydroxy-2oxo-1,2-dihydroquinoline-3-carboxylic acids [16] and structurally-related heterocyclic systems $[17,18]$ the present communication is devoted to $N$-(benzyl)-2hydroxy-4-oxo-4H-pyrido[1,2-a] pyrimidine-3-carboxamides methylated in position 8 of the pyridopyrimidine nucleus. The relatively high analgesic properties recently discovered in $N$-(benzyl)-2-hydroxy9-methyl-4-oxo-4H-pyrido[1,2-a]pyrimidine-3-carboxamides [19] were the theoretical background to involvement of these compounds to the range of the objects studied. A detailed analysis of the structure of these substances indicates that the attempt can be made to intensify their biological effect by the chemical modification of the pyridine moiety of the molecule bicyclic base, namely by displacement of the methyl group to another position, for example position 8 .

It is clear that it is advisable to start the practical implementation of such a transformation with a product containing the methyl group in the intentionally required position - in this case it is a com- mercially available 2-amino-4-methylpyridine (1). Condensation of this amine with triethyl methanetricarboxylate (2) through the intermediate monoamide (3) gives ethyl 2-hydroxy-8-methyl-4-oxo-4H-pyrido [1,2-a]pyrimidine-3-carboxylate (4) [20] (see Scheme), the subsequent amidation of it leads to the target $N$-(benzyl)-2-hydroxy-8-methyl-4-oxo- $4 H$-pyrido [1,2-a]pyrimidine-3-carboxamides (5a-n) with high yields and purity.

All of the N-(benzyl)-2-hydroxy-8-methyl-4-oxo$4 \mathrm{H}$-pyrido[1,2-a]pyrimidine-3-carboxamides (5a-n) obtained are colourless crystalline substances with the narrow intervals of melting points (Table 1). At room temperature they are sparingly soluble in DMF and DMSO, slightly soluble in low alcohols and insoluble in water.

The structure of the compounds obtained has been confirmed by elemental analysis (Table 1 ) and ${ }^{1} \mathrm{H}$ NMR spectroscopy (Table 2). The signals of protons of 2-OH groups in the ${ }^{1} \mathrm{H}$ NMR spectra resonate in the weak field that is characteristic for enols - 15.91-15.63 ppm. The terminal amide groups are present in triplets common for them (or doublets in the case of 1-phenylethylamides 51-n) in the region of 9.98-9.82 ppm. The proximity of the proton in position 6 with an electronegative cyclic nitrogen atom causes its strong paramagnetic shift with respect to the other protons of the pyridine moiety (see Fig.). Interestingly, the resonance signals of protons of $\mathrm{H}-7$ and $\mathrm{H}-9$ in all $\mathrm{N}$-(benzyl)-2-hydroxy-8-methyl-4-oxo-4H-pyrido[1,2-a]pyrimidine-3-carboxamides (5a-n) change places compared to those in the ${ }^{1} \mathrm{H}$ NMR spectrum of the starting ester (4) [20]. It is ratter difficult to give an unambiguous explanation for this fact without more research since this effect was not observed in 9-methyl substituted isomers previously studied [19]. The signals of aromatic protons of arylalkylamide fragments, as a rule, are markedly shifted upfield and focused

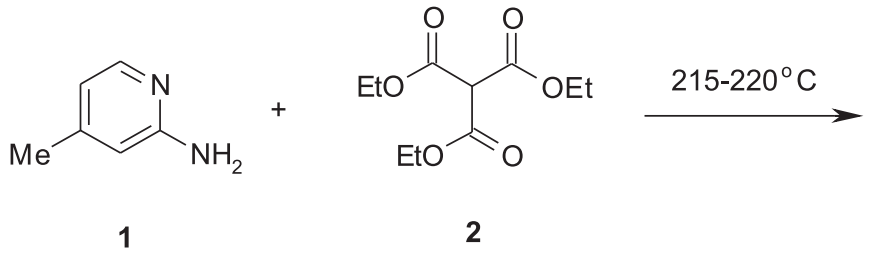<smiles>CCOC(=O)c1c(O)nc2cc(C)ccn2c1=O</smiles>

4<smiles>CCOC(=O)C(C(=O)Nc1cc(C)ccn1)C(=O)OCC</smiles>

3

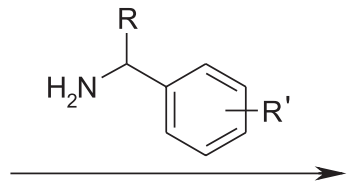

$\mathrm{EtOH}, 80^{\circ} \mathrm{C}, 48 \mathrm{~h}$<smiles>[R]c1ccc(C([R])NC(=O)c2c(O)nc3cc(C)ccn3c2=O)cc1</smiles>

5a-n

2: $\mathrm{R}=\mathrm{H}-\mathbf{a} \mathrm{R}^{\prime}=\mathrm{H}$; b R' = 4-F; c R' = 2-Cl; d R' = 4-Cl; e R' = 2-Me; f R' = 3-Me; g R' = 4-Me; h R' = 2-OMe;

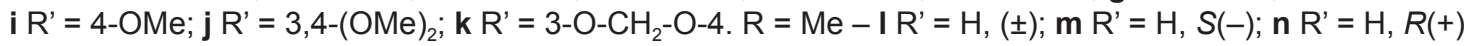


Characteristics of benzylamides $\mathbf{5 a - n}$

\begin{tabular}{|c|c|c|c|c|c|c|}
\hline \multirow[t]{2}{*}{ Compound } & \multirow{2}{*}{$\begin{array}{l}\text { Empirical } \\
\text { formula }\end{array}$} & \multicolumn{3}{|c|}{$\frac{\text { Found, } \%}{\text { Calculated, } \%}$} & \multirow[t]{2}{*}{ M.p., ${ }^{\circ} \mathrm{C}$} & \multirow[t]{2}{*}{ Yield, \% } \\
\hline & & $C$ & $\mathrm{H}$ & $\mathrm{N}$ & & \\
\hline $5 a$ & $\mathrm{C}_{17} \mathrm{H}_{15} \mathrm{~N}_{3} \mathrm{O}_{3}$ & $\frac{66.12}{66.01}$ & $\frac{4.80}{4.89}$ & $\frac{13.52}{13.58}$ & $222-224$ & 88 \\
\hline $5 b$ & $\mathrm{C}_{17} \mathrm{H}_{14} \mathrm{FN}_{3} \mathrm{O}_{3}$ & $\frac{62.29}{62.38}$ & $\frac{4.37}{4.31}$ & $\frac{12.92}{12.84}$ & 196-198 & 92 \\
\hline $5 c$ & $\mathrm{C}_{17} \mathrm{H}_{14} \mathrm{CIN}_{3} \mathrm{O}_{3}$ & $\frac{59.33}{59.40}$ & $\frac{4.04}{4.10}$ & $\frac{12.15}{12.22}$ & 203-205 & 94 \\
\hline $5 d$ & $\mathrm{C}_{17} \mathrm{H}_{14} \mathrm{ClN}_{3} \mathrm{O}_{3}$ & $\frac{59.45}{59.40}$ & $\frac{4.03}{4.10}$ & $\frac{12.28}{12.22}$ & $244-246$ & 90 \\
\hline $5 e$ & $\mathrm{C}_{18} \mathrm{H}_{17} \mathrm{~N}_{3} \mathrm{O}_{3}$ & $\frac{66.91}{66.86}$ & $\frac{5.36}{5.30}$ & $\frac{12.95}{13.00}$ & $210-212$ & 87 \\
\hline $5 f$ & $\mathrm{C}_{18} \mathrm{H}_{17} \mathrm{~N}_{3} \mathrm{O}_{3}$ & $\frac{66.77}{66.86}$ & $\frac{5.23}{5.30}$ & $\frac{13.07}{13.00}$ & 199-201 & 84 \\
\hline $5 g$ & $\mathrm{C}_{18} \mathrm{H}_{17} \mathrm{~N}_{3} \mathrm{O}_{3}$ & $\frac{66.82}{66.86}$ & $\frac{5.33}{5.30}$ & $\frac{13.11}{13.00}$ & 191-193 & 88 \\
\hline $5 \mathrm{~h}$ & $\mathrm{C}_{18} \mathrm{H}_{17} \mathrm{~N}_{3} \mathrm{O}_{4}$ & $\frac{63.63}{63.71}$ & $\frac{5.14}{5.05}$ & $\frac{12.46}{12.38}$ & $186-188$ & 89 \\
\hline $5 i$ & $\mathrm{C}_{18} \mathrm{H}_{17} \mathrm{~N}_{3} \mathrm{O}_{4}$ & $\frac{63.79}{63.71}$ & $\frac{5.12}{5.05}$ & $\frac{12.30}{12.38}$ & $225-227$ & 86 \\
\hline $5 \mathrm{j}$ & $\mathrm{C}_{19} \mathrm{H}_{19} \mathrm{~N}_{3} \mathrm{O}_{5}$ & $\frac{61.88}{61.78}$ & $\frac{5.25}{5.18}$ & $\frac{11.44}{11.38}$ & 202-204 & 89 \\
\hline $5 k$ & $\mathrm{C}_{18} \mathrm{H}_{15} \mathrm{~N}_{3} \mathrm{O}_{5}$ & $\frac{61.13}{61.19}$ & $\frac{4.23}{4.28}$ & $\frac{11.96}{11.89}$ & $238-240$ & 95 \\
\hline 51 & $\mathrm{C}_{18} \mathrm{H}_{17} \mathrm{~N}_{3} \mathrm{O}_{3}$ & $\frac{66.91}{66.86}$ & $\frac{5.24}{5.30}$ & $\frac{13.09}{13.00}$ & $170-172$ & 80 \\
\hline $5 m^{*}$ & $\mathrm{C}_{18} \mathrm{H}_{17} \mathrm{~N}_{3} \mathrm{O}_{3}$ & $\frac{66.77}{66.86}$ & $\frac{5.42}{5.30}$ & $\frac{13.12}{13.00}$ & $175-177$ & 81 \\
\hline $5 n^{* *}$ & $\mathrm{C}_{18} \mathrm{H}_{17} \mathrm{~N}_{3} \mathrm{O}_{3}$ & $\frac{66.82}{66.86}$ & $\frac{5.39}{5.30}$ & $\frac{12.93}{13.00}$ & $175-177$ & 83 \\
\hline
\end{tabular}

$*[\mathrm{a}]^{20}{ }_{\mathrm{D}}=+18.6 ; c=5 ; \mathrm{DMF}$.

$* *[\mathrm{a}]^{20}{ }_{\mathrm{D}}=-18.6 ; c=5 ;$ DMF.

on the narrow segments of spectra appearing often in the spectra by complex multiplets. Therefore, assignment of these signals to any particular benzylamide proton becomes difficult, if not impossible (Table 2). However, the need for such assignments is not obligatory - the total integrated intensity of these signals is enough to confirm the structure of the $\mathrm{N}$-(benzyl)-2-hydroxy-8-methyl-4-oxo-4H-pyrido[1,2-a]pyrimidine-3-carboxamides (5a-n) studied.

As one should expect, chiral 1-phenylethylamides (5m and $\mathbf{5 n})$ have absolutely identical ${ }^{1} \mathrm{H}$ NMR spectra with the racemate (5l) and the same values of specific rotation differing only by signs (see Table 1 and 2). Since the total chemical individuality of enantiomeric substances is not a guarantee for their purity in the sense of stereochemistry, then in the case of 1-phenylethylamides ( $\mathbf{5 m}$ and $\mathbf{5 n}$ ) there is also a need to determine the optical purity. This is despite the fact that in their synthesis the optically pure S (-) - and R(+)-1-phenylethylamines (see Experimental Part) having a high optical stability and being not susceptible to racemization during acylation were used [21]. It is due to the large number of diverse external factors that can cause racemization of chiral substances.

We tried to determine the enantiomeric purity of 1-phenylethylamides (5m and $\mathbf{5 n}$ ) using ${ }^{1} \mathrm{H}$ NMR spectroscopy and chiral lanthanide shift reagents (LSR). Depending on the purity of the sample under study their addition results in formation of one or two diastereomers, in which protons become magnetically nonequivalent. In its turn, it is easily determined by doubling of some signals in the ${ }^{1} \mathrm{H}$ NMR spectrum [22]. Unfortunately, our experiments have failed. Adding tris[3-(heptafluoropropylhydroxymethylene)-(+)-camphorato]europium(III) to the solutions of chiral 1-phenylethylamides ( $\mathbf{5 m}$ and $\mathbf{5 n}$ ) and even to their optically inactive racemic mixture (5l) 


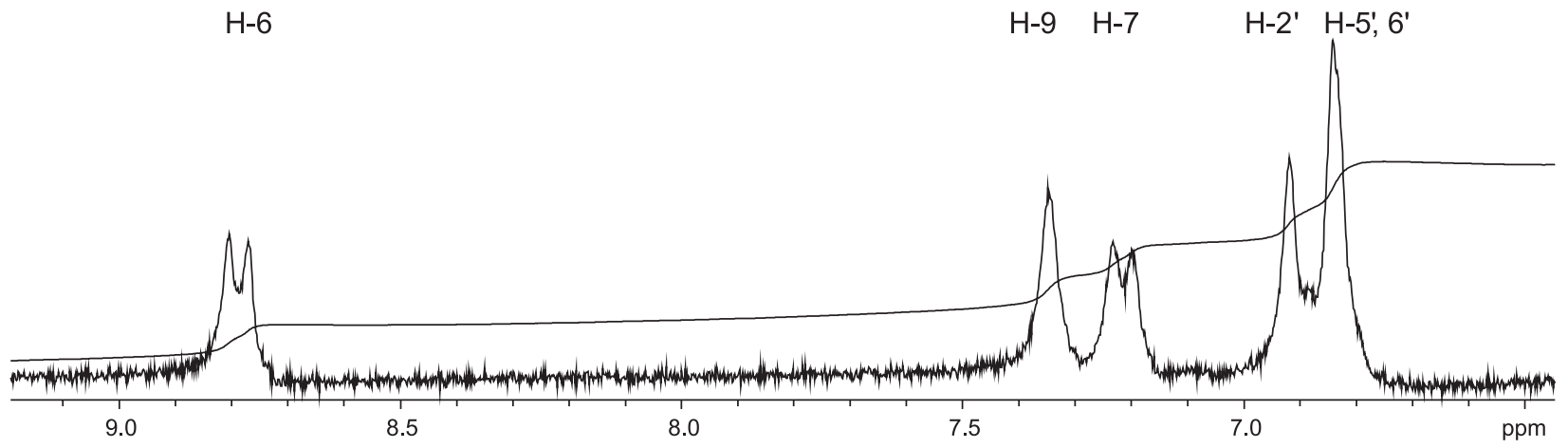

Fig. A fragment of the ${ }^{1} \mathrm{H}$ NMR spectra (signals of aromatic protons) of amide $\mathbf{5 k}$.

is not accompanied with duplication of any signals, it leads only to broadening of the majority of the spectral signals. This result is obviously caused by the strongly expressed acidic properties of the substances analyzed due to their 2-OH groups.
As it is known [21], obtaining of both antipodes with the same absolute value of the optical rotation can serve as a fairly reliable characteristic of the complete optical purity, especially if both enantiomers are obtained independently by using a variety of asym-

Table 2

${ }^{1} \mathrm{H}$ NMR Spectra of benzylamides 5a-n

\begin{tabular}{|c|c|}
\hline Compound & Chemical shifts, $\delta$, ppm $(J, \mathrm{~Hz})$ \\
\hline $5 a$ & $\begin{array}{l}15.86(1 \mathrm{H}, \mathrm{s}, 2-\mathrm{OH}) ; 9.93(1 \mathrm{H}, \mathrm{t}, J=6.0, \mathrm{NH}) ; 8.80(1 \mathrm{H}, \mathrm{d}, J=7.1, \mathrm{H}-6) ; 7.38-7.19(7 \mathrm{H}, \mathrm{m}, \mathrm{H}-7.9+\mathrm{Ph}) ; \\
4.57\left(2 \mathrm{H}, \mathrm{d}, J=6.1, \mathrm{CONHC} \underline{H}_{2}\right) ; 2.42(3 \mathrm{H}, \mathrm{s}, 8-\mathrm{Me})\end{array}$ \\
\hline $5 b$ & $\begin{array}{l}15.82(1 \mathrm{H}, \mathrm{s}, 2-\mathrm{OH}) ; 9.92(1 \mathrm{H}, \mathrm{t}, J=6.1, \mathrm{NH}) ; 8.79(1 \mathrm{H}, \mathrm{d}, J=6.9, \mathrm{H}-6) ; 7.45-7.09\left(6 \mathrm{H}, \mathrm{m}, \mathrm{H}-7.9+\mathrm{H}-3^{\prime}, 5^{\prime}+\right. \\
\left.\mathrm{H}-2^{\prime}, 6^{\prime}\right) ; 4.55\left(2 \mathrm{H}, \mathrm{d}, J=6.0, \mathrm{CONHC} \underline{H}_{2}\right) ; 2.42(3 \mathrm{H}, \mathrm{s}, 8-\mathrm{Me})\end{array}$ \\
\hline $5 c$ & $\begin{array}{l}15.63(1 \mathrm{H}, \mathrm{s}, 2-\mathrm{OH}) ; 9.98(1 \mathrm{H}, \mathrm{t}, J=6.0, \mathrm{NH}) ; 8.82(1 \mathrm{H}, \mathrm{d}, J=7.2, \mathrm{H}-6) ; 7.50-7.21\left(6 \mathrm{H}, \mathrm{m}, \mathrm{H}-7.9+\mathrm{H}-3^{\prime}, 4^{\prime}, 5^{\prime}, 6^{\prime}\right) ; \\
4.65\left(2 \mathrm{H}, \mathrm{d}, J=6.1, \mathrm{CONHC} \underline{H}_{2}\right) ; 2.43(3 \mathrm{H}, \mathrm{s}, 8-\mathrm{Me})\end{array}$ \\
\hline $5 d$ & $\begin{array}{l}15.79(1 \mathrm{H}, \mathrm{s}, 2-\mathrm{OH}) ; 9.95(1 \mathrm{H}, \mathrm{t}, J=6.0, \mathrm{NH}) ; 8.81(1 \mathrm{H}, \mathrm{d}, J=7.1, \mathrm{H}-6) ; 7.43-7.33\left(5 \mathrm{H}, \mathrm{m}, \mathrm{H}-9+\mathrm{H}-2^{\prime}, 3^{\prime}, 5^{\prime}, 6^{\prime}\right) ; \\
7.22(1 \mathrm{H}, \mathrm{d}, J=7.1, \mathrm{H}-7) ; 4.56\left(2 \mathrm{H}, \mathrm{d}, J=6.2, \mathrm{CONHC} \underline{H}_{2}\right) ; 2.41(3 \mathrm{H}, \mathrm{s}, 8-\mathrm{Me})\end{array}$ \\
\hline $5 e$ & $\begin{array}{l}15.81(1 \mathrm{H}, \mathrm{s}, 2-\mathrm{OH}) ; 9.82(1 \mathrm{H}, \mathrm{t}, J=5.6, \mathrm{NH}) ; 8.79(1 \mathrm{H}, \mathrm{d}, J=7.1, \mathrm{H}-6) ; 7.35(1 \mathrm{H}, \mathrm{s}, \mathrm{H}-9) ; 7.28-7.13(5 \mathrm{H}, \mathrm{m}, \\
\left.\mathrm{H}-7+\mathrm{H}-3^{\prime}, 4^{\prime}, 5^{\prime}, 6^{\prime}\right) ; 4.55\left(2 \mathrm{H}, \mathrm{d}, J=5.6, \mathrm{CONHC} \underline{H}_{2}\right) ; 2.42(3 \mathrm{H}, \mathrm{s}, 8-\mathrm{Me}) ; 2.31\left(3 \mathrm{H}, \mathrm{s}, 2^{\prime}-\mathrm{Me}\right)\end{array}$ \\
\hline $5 f$ & $\begin{array}{l}15.85(1 \mathrm{H}, \mathrm{s}, 2-\mathrm{OH}) ; 9.88(1 \mathrm{H}, \mathrm{t}, J=5.9, \mathrm{NH}) ; 8.79(1 \mathrm{H}, \mathrm{d}, J=7.3, \mathrm{H}-6) ; 7.35(1 \mathrm{H}, \mathrm{s}, \mathrm{H}-9) ; 7.25-7.03(5 \mathrm{H}, \mathrm{m}, \\
\left.\mathrm{H}-7+\mathrm{H}-2^{\prime}, 4^{\prime}, 5^{\prime}, 6^{\prime}\right) ; 4.53\left(2 \mathrm{H}, \mathrm{d}, J=6.0, \mathrm{CONHC} \underline{H}_{2}\right) ; 2.43(3 \mathrm{H}, \mathrm{s}, 8-\mathrm{Me}) ; 2.27\left(3 \mathrm{H}, \mathrm{s}, 3^{\prime}-\mathrm{Me}\right)\end{array}$ \\
\hline $5 g$ & $\begin{array}{l}15.89(1 \mathrm{H}, \mathrm{s}, 2-\mathrm{OH}) ; 9.89(1 \mathrm{H}, \mathrm{t}, J=5.5, \mathrm{NH}) ; 8.79(1 \mathrm{H}, \mathrm{d}, J=7.0, \mathrm{H}-6) ; 7.35(1 \mathrm{H}, \mathrm{s}, \mathrm{H}-9) ; 7.22(2 \mathrm{H}, \mathrm{d}, J=7.7, \\
\left.\mathrm{H}-2^{\prime}, 6^{\prime}\right) ; 7.12\left(2 \mathrm{H}, \mathrm{d}, J=7.7, \mathrm{H}-3^{\prime}, 5^{\prime}\right) ; 4.52\left(2 \mathrm{H}, \mathrm{d}, J=5.5, \mathrm{CONHC} \underline{H}_{2}\right) ; 2.41(3 \mathrm{H}, \mathrm{s}, 8-\mathrm{Me}) ; 2.26\left(3 \mathrm{H}, \mathrm{s}, 4^{\prime}-\mathrm{Me}\right)\end{array}$ \\
\hline $5 \mathrm{~h}$ & $\begin{array}{l}15.86(1 \mathrm{H}, \mathrm{s}, 2-\mathrm{OH}) ; 9.89(1 \mathrm{H}, \mathrm{t}, J=6.1, \mathrm{NH}) ; 8.81(1 \mathrm{H}, \mathrm{d}, J=7.3, \mathrm{H}-6) ; 7.34(1 \mathrm{H}, \mathrm{s}, \mathrm{H}-9) ; 7.29-6.86(5 \mathrm{H}, \mathrm{m}, \\
\left.\mathrm{H}-7+\mathrm{H}-3^{\prime}, 4^{\prime}, 5^{\prime}, 6^{\prime}\right) ; 4.53\left(2 \mathrm{H}, \mathrm{d}, J=6.0, \mathrm{CONHC} \underline{H}_{2}\right) ; 3.85(3 \mathrm{H}, \mathrm{s}, \mathrm{OMe}) ; 2.42(3 \mathrm{H}, \mathrm{s}, 8-\mathrm{Me})\end{array}$ \\
\hline $5 i$ & $\begin{array}{l}15.91(1 \mathrm{H}, \mathrm{s}, 2-\mathrm{OH}) ; 9.83(1 \mathrm{H}, \mathrm{t}, J=5.7, \mathrm{NH}) ; 8.77(1 \mathrm{H}, \mathrm{d}, J=7.3, \mathrm{H}-6) ; 7.33(1 \mathrm{H}, \mathrm{s}, \mathrm{H}-9) ; 7.27(2 \mathrm{H}, \mathrm{d}, J=8.9, \\
\left.\mathrm{H}-3^{\prime}, 5^{\prime}\right) ; 7.20(1 \mathrm{H}, \mathrm{d}, J=7.1, \mathrm{H}-7) ; 6.88\left(2 \mathrm{H}, \mathrm{d}, J=8.9, \mathrm{H}-2^{\prime}, 6^{\prime}\right) ; 4.49\left(2 \mathrm{H}, \mathrm{d}, J=5.7, \mathrm{CONHC} \underline{\mathrm{H}}_{2}\right) ; 3.71(3 \mathrm{H}, \mathrm{s}, \\
\mathrm{OMe}) ; 2.42(3 \mathrm{H}, \mathrm{s}, 8-\mathrm{Me})\end{array}$ \\
\hline $5 j$ & $\begin{array}{l}15.93(1 \mathrm{H}, \mathrm{s}, 2-\mathrm{OH}) ; 9.84(1 \mathrm{H}, \mathrm{t}, J=5.6, \mathrm{NH}) ; 8.79(1 \mathrm{H}, \mathrm{d}, J=7.0, \mathrm{H}-6) ; 7.36(1 \mathrm{H}, \mathrm{s}, \mathrm{H}-9) ; 7.22(1 \mathrm{H}, \mathrm{d}, J=7.2, \\
\mathrm{H}-7) ; 6.98\left(1 \mathrm{H}, \mathrm{s}, \mathrm{H}-2^{\prime}\right) ; 6.94-6.83\left(2 \mathrm{H}, \mathrm{m}, \mathrm{H}-5^{\prime}, 6^{\prime}\right) ; 4.49\left(2 \mathrm{H}, \mathrm{d}, J=5.6, \mathrm{CONHC} \underline{\mathrm{H}}_{2}\right) ; 3.72(6 \mathrm{H}, \mathrm{s}, \mathrm{OMe} \times 2) ; \\
2.41(3 \mathrm{H}, \mathrm{s}, 8-\mathrm{Me})\end{array}$ \\
\hline $5 \mathrm{k}$ & $\begin{array}{l}15.87(1 \mathrm{H}, \mathrm{s}, 2-\mathrm{OH}) ; 9.85(1 \mathrm{H}, \mathrm{t}, J=5.4, \mathrm{NH}) ; 8.78(1 \mathrm{H}, \mathrm{d}, J=6.8, \mathrm{H}-6) ; 7.35(1 \mathrm{H}, \mathrm{s}, \mathrm{H}-9) ; 7.21(1 \mathrm{H}, \mathrm{d}, J=6.8 \\
\mathrm{H}-7) ; 6.92\left(1 \mathrm{H}, \mathrm{s}, \mathrm{H}-2^{\prime}\right) ; 6.86-6,82\left(2 \mathrm{H}, \mathrm{m}, \mathrm{H}-5^{\prime}, 6^{\prime}\right) ; 5.97\left(2 \mathrm{H}, \mathrm{s}, \mathrm{O}-\mathrm{CH}_{2}-\mathrm{O}\right) ; 4.46\left(2 \mathrm{H}, \mathrm{d}, J=5.4, \mathrm{CONHC} \underline{\mathrm{H}}_{2}\right) ; \\
2.43(3 \mathrm{H}, \mathrm{s}, 8-\mathrm{Me})\end{array}$ \\
\hline 51 & $\begin{array}{l}15.70(1 \mathrm{H}, \mathrm{s}, 2-\mathrm{OH}) ; 9.93(1 \mathrm{H}, \mathrm{d}, J=7.0, \mathrm{NH}) ; 8.81(1 \mathrm{H}, \mathrm{d}, J=7.1, \mathrm{H}-6) ; 7.45-7.19(7 \mathrm{H}, \mathrm{m}, \mathrm{H}-7.9+\mathrm{Ph}) \\
5.17(1 \mathrm{H}, \mathrm{q}, J=7.0, \mathrm{CONHC}) ; 2.42(3 \mathrm{H}, \mathrm{s}, 8-\mathrm{Me}) ; 1.51(3 \mathrm{H}, \mathrm{d}, J=7.0, \mathrm{CH}-\underline{\mathrm{Me}})\end{array}$ \\
\hline $5 \mathrm{~m}$ & $\begin{array}{l}15.70(1 \mathrm{H}, \mathrm{s}, 2-\mathrm{OH}) ; 9.93(1 \mathrm{H}, \mathrm{d}, J=7.0, \mathrm{NH}) ; 8.81(1 \mathrm{H}, \mathrm{d}, J=7.1, \mathrm{H}-6) ; 7.45-7.19(7 \mathrm{H}, \mathrm{m}, \mathrm{H}-7.9+\mathrm{Ph}) ; \\
5.17(1 \mathrm{H}, \mathrm{q}, J=7.0, \mathrm{CONHC} \underline{\mathrm{H}}) ; 2.42(3 \mathrm{H}, \mathrm{s}, 8-\mathrm{Me}) ; 1.51(3 \mathrm{H}, \mathrm{d}, J=7.0, \mathrm{CH}-\underline{\mathrm{Me}})\end{array}$ \\
\hline $5 n$ & $\begin{array}{l}15.70(1 \mathrm{H}, \mathrm{s}, 2-\mathrm{OH}) ; 9.93(1 \mathrm{H}, \mathrm{d}, J=7.0, \mathrm{NH}) ; 8.81(1 \mathrm{H}, \mathrm{d}, J=7.1, \mathrm{H}-6) ; 7.45-7.19(7 \mathrm{H}, \mathrm{m}, \mathrm{H}-7,9+\mathrm{Ph}) ; \\
5.17(1 \mathrm{H}, \mathrm{q}, J=7.0, \mathrm{CONHC} \underline{\mathrm{H}}) ; 2.42(3 \mathrm{H}, \mathrm{s}, 8-\mathrm{Me}) ; 1.51(3 \mathrm{H}, \mathrm{d}, J=7.0, \mathrm{CH}-\underline{\mathrm{Me}})\end{array}$ \\
\hline
\end{tabular}


metric reagents. Both the characteristics of 1-phenylethylamides themselves (5m and $\mathbf{5 n}$ ) and the conditions for their synthesis correspond to all these criteria. Therefore, there is every reason to consider these substances to be optically pure enantiomers.

In principle, the true spatial configuration of the substance and direction of rotation of the polarization plane are unrelated characteristics [21]. Therefore, rotation of the polarization plane by amides ( $5 \mathrm{~m}$ and $\mathbf{5 n}$ ) in the opposite direction compared to the starting amines should be considered only as an interesting fact. Moreover, rotation of the configuration (especially the complete one) when acylating chiral 1-phenylethylamines is not observed [23].

The analgesic properties of the compounds synthesized were studied in full compliance with the provisions of the European Convention for the Protection of Vertebrate Animals used for Experimental and other Scientific Purposes, and the Law of Ukraine No. 3447=IV "On protection of animals from cruel behaviour" (2006). During the study the experimental animals were kept on a standard diet with free access to food and water.

Screening tests were performed on nonlinear white male mice weighing 18-23 g on the standard experimental model of "acetic acid writhing" [24]. The nociceptive effect was reproduced by intraperitoneal injection of $0.6 \%$ solution of $\mathrm{AcOH}(0.1 \mathrm{ml}$ per $10 \mathrm{~g}$ of the body weight) in $1 \mathrm{~h}$ after oral administration of the test sample. Observations of the animals were within 20 min by counting the number of "writhings". The assessment of the analgesic effect was carried out by the ability of test substances to reduce the number of "writhings" in comparison with the untreated control and expressed as a percentage (Table 3). The well-known non-narcotic analgesics Piroxicam and Nabumetone were used as the reference drugs. All $N$-(benzyl)-2-hydroxy-8-methyl-4-oxo- $4 H$ pyrido[1,2-a]pyrimidine-3-carboxamides (5a-n) under study were introduced as a fine aqueous suspension stabilized with Tween- 80 (20 mg/kg, orally). The reference drugs were introduced in the doses similar to their corresponding $\mathrm{ED}_{50}$ for the experimental model used [25]. The control animals received an equivalent amount of water and Tween-80. Seven experimental animals were involved to obtain statistically reliable results (in this work the significance level of the confidence interval is taken as $p \leq 0.05$ ) in testing each of the compounds synthesized, reference drugs and control. Data from all biological tests were processed using the t-Student's test [26].

A detailed analysis of our experimental data (Table 3) shows a very interesting structural and biological regularity: displacement of the methyl group from position 9 of the pyrido [1,2-a] pyrimidine nucleus to position 8 is accompanied with a marked increase of the analgesic properties of exclusively para-substituted $N$-(benzyl)-2-hydroxy-8-methyl-4-
Table 3

The analgesic properties of benzylamides 5a-n

\begin{tabular}{|c|c|c|}
\hline \multirow{2}{*}{ Compound } & \multicolumn{2}{|c|}{ Analgesic activity } \\
\cline { 2 - 3 } & $\begin{array}{c}\text { Average amount of } \\
\text { "acetic acid writhing" }\end{array}$ & \%* \\
\hline $5 \mathrm{a}$ & $38.9 \pm 1.7$ & $51.1(52.3)$ \\
\hline $5 \mathrm{~b}$ & $29.9 \pm 1.2$ & $62.4(31.5)$ \\
\hline $5 \mathrm{c}$ & $57.5 \pm 3.3$ & $27.6(32.7)$ \\
\hline $5 \mathrm{~d}$ & $35.1 \pm 1.4$ & $55.8(51.2)$ \\
\hline $5 \mathrm{e}$ & $71.2 \pm 3.8$ & $10.3(11.8)$ \\
\hline $5 \mathrm{f}$ & $69.5 \pm 3.4$ & $12.5(17.1)$ \\
\hline $5 \mathrm{~g}$ & $53.0 \pm 2.6$ & $33.2(16.4)$ \\
\hline $5 \mathrm{~h}$ & $65.9 \pm 3.1$ & $16.9(26.7)$ \\
\hline $5 \mathrm{i}$ & $40.7 \pm 1.9$ & $48.7(25.6)$ \\
\hline $5 \mathrm{j}$ & $51.2 \pm 2.2$ & $35.5(42.4)$ \\
\hline $5 \mathrm{k}$ & $61.7 \pm 3.0$ & $22.3(29.1)$ \\
\hline $5 \mathrm{l}$ & $67.0 \pm 3.5$ & $15.6(18.2)$ \\
\hline $5 \mathrm{~m}$ & $66.5 \pm 3.3$ & $16.3(16.9)$ \\
\hline $5 \mathrm{n}$ & $64.8 \pm 3.0$ & $18.4(17.5)$ \\
\hline $\begin{array}{l}\text { Piroxicam } \\
(92 \mathrm{mg} / \mathrm{kg})\end{array}$ & $39.3 \pm 1.9$ & 50.5 \\
\hline $\begin{array}{l}\text { Nabumetone } \\
(50 \mathrm{mg} / \mathrm{kg})\end{array}$ & $40.6 \pm 2.1$ & 48.9 \\
\hline Control & $79.4 \pm 2.7$ & - \\
\hline
\end{tabular}

* Figures in parentheses are the analgesic activity of the corresponding isomeric $\mathrm{N}$-(benzyl)-2-hydroxy-9-methyl-4-oxo-4H-pyrido[1,2-a] pyrimidine-3-carboxamides studied under the same conditions [19].

oxo-4H-pyrido[1,2-a]pyrimidine-3-carboxamides (5b, $\mathbf{5 d}, \mathbf{5 g}$ and $\mathbf{5 i}$ ). Thus, the analgesic effect of the orthoand meta-substituted derivatives remains nearly at the same level. There is also no effect of this modification on the activity of 1-phenylethylamides (5l-n), i.e. the presence of the methyl group in the methylene bridge separating the aromatic ring and the amide nitrogen atom should be clearly recognized as an undesirable factor.

Of the whole group $\mathrm{N}$-(4-fluorobenzyl)-2-hydroxy8-methyl-4-oxo-4H-pyrido[1,2-a]pyrimidine-3-carboxamide (5b) is of particular interest; by the level of its analgesic action it substantially exceeds Piroxicam and Nabumetone in much lower dose. On this basis it can be recommended for profound pharmacological trials as a potential new analgesic.

\section{Experimental Part}

The ${ }^{1} \mathrm{H}$ NMR spectra were recorded on a Varian Mercury-400 spectrometer (400 MHz) in DMSO- $\mathrm{d}_{6}$ solution, the internal standard was TMS. Elemental analysis was carried out on a EuroVector EA-3000 microanalyzer. Melting points were determined in capillaries on a SMP10 Stuart digital melting point analyzer. The specific rotation of the optically active 
amides $\mathbf{3 m}, \mathbf{n}$ was determined on a Polamat A polarimeter. These syntheses use commercially $S(-)$ and $R(+)-1$-phenylethylamines from Fluka with an optical purity of at least $99.5 \%$. The starting ethyl 2-hydroxy-8-methyl-4-oxo-4H-pyrido[1,2-a]pyrimidine-3-carboxylate (4) was synthesized according to the literature procedure [20].

The general procedure of obtaining $N$-(benzyl)-2-hydroxy-8-methyl-4-oxo-4H-pyrido[1,2-a] pyrimidine-3-carboxamides (5a-n). Add $0.02 \mathrm{Mol}$ of the corresponding benzylamine to the solution of $2.48 \mathrm{~g}(0.01 \mathrm{Mol})$ of ethyl 2-hydroxy-8-methyl4-oxo-4H-pyrido[1,2-a]pyrimidine-3-carboxylate (2) in 10-15 $\mathrm{ml}$ of EtOH and reflux for $30 \mathrm{~h}$. Stop heating the reaction mixture, then cool and allow to stand at a temperature of about $0^{\circ} \mathrm{C}$ for $10-12 \mathrm{~h}$. Filter the precipitate of benzylamide (5a-n) isolated, first wash with a cold hexane, then with water and dry in the air. Crystallize from the mixture of DMF ethanol (1:1).

\section{Conclusions}

1. For the purpose of the possible increase in analgesic properties the chemical modification of the compounds previously studied has been performed; as a result, the synthesis of a series of $N$-(benzyl)2-hydroxy-8-methyl-4-oxo-4H-pyrido[1,2-a]pyrimidine-3-carboxamides has been carried out.

2 . According to the results of the pharmacological trials it has been found that in some cases displacement of the methyl group from position 9 of the pyridopyrimidine nucleus to position 8 is accompanied with a noticeable increase in the analgesic activity.

\section{References}

1. Kubinyi H. Rossiiskii Khimicheskii Zhurnal - Russian Chemical Journal, 2006, Vol. L, No.2, pp.5-17.

2. Xiong W., Ma X., Wu Y., Chen Y., Zeng L., Liu J., Sun W., Wang D., Hu Y. BMC Veterinary Research, 2015, No.11, pp.205. D0I: 10.1186/s12917-015-0459-9.

3. Kang Y. G., Park C. Y., Shin H., Singh R., Arora G., Yu C. M., Lee I. Y. Bioorganic \& Medicinal Chemistry Letters, 2015, Vol. 25, No.17, pp.3650-3653. D0I: 10.1016/j.bmcl.2015.06.060.

4. Weng X., Baez J. E., Khiterer M., Hoe M. Y., Bao Z., Shea K. J. Angewandte Chemie (International ed. in English), 2015, Vol. 54, No.38, pp.11214-11218. DOI: 10.1002 /anie.201504934.

5. Murakami T., Okamoto H., Kim H. Biomaterials Science, 2015, Vol. 3, No.5, pp.712-715. DOI: 10.1039/c4bm00402g.

6. Uchida S., Kataoka K., Itaka K. Pharmaceutics, 2015, Vol. 7, No.3, pp.137-151. DOI: 10.3390/pharmaceutics7030137.

7. Ahmed S. A., El-Shayeb N. M., Hashem A. G., Saleh S. A., Abdel-Fattah A. F. Brazilian Journal of Microbiology: [publication of the Brazilian Society for Microbiology], 2015, Vol. 46, No.1, pp.23-28. DOI: 10.1590/S1517-838246120120462.

8. Kirdponpattara S., Khamkeaw A., Sanchavanakit N., Pavasant P., Phisalaphong M. Carbohydrate Polymers, 2015, No.132, pp.146-155. D0I: 10.1016/j. carbpol.2015.06.059.

9. Du H., Liu M., Yang X., Zhai G. Journal of Colloid and Interface Science, 2015, No.460, pp.87-96. D0I: 10.1016/j.jcis.2015.08.049.

10. Sureshbabu A. R., Kurapati R., Russier J., Ménard-Moyon C., Bartolini I., Meneghetti M., Kostarelos K., Bianco A. Biomaterials, 2015 , No.72, pp.20-28. DOI: 10.1016/j.biomaterials.2015.08.046.

11. Kuznetsov S. G., Chigareva S. M., Ramsh S. M. Itogi nauki i tekhniki. Organicheskaya Khimiya (The results of science and technology. Organic chemistry). Moscow, VINITI; 1991, Vol. 19, pp.25-54.

12. Fijałkowski K., Żywicka A., Drozd R., Niemczyk A., Junka A. F., Peitler D., Kordas M., Konopacki M., Szymczyk P., Fray M. E., Rakoczy R. Carbohydrate Polymers, 2015, No.133, pp.52-60. DOI: 10.1016/j.carbpol.2015.07.011.

13. Guilini C., Baehr C., Schaeffer E., Gizzi P., Rufi F., Haiech J., Weiss E., Bonnet D, Galzi J. L. Analytical Chemistry, 2015, Vol. 87, No.17, pp.8858-8866. DOI: 10.1021/acs.analchem.5b02100.

14. Morrison P. M., Foley P. J., Warriner S. L., Webb M. E. Chemical Communications (Cambridge, England), 2015, Vol. 51, No.70, pp.13470-13473. DOI: 10.1039/c5cc05469a.

15. Nilsen T. W. Cold Spring Harbor protocols, 2015, Vol. 2015, No.6, pp.599-603. DOI: 10.1101/pdb.prot081059.

16. Ukrainets I. V., Gorokhova O. V., Nidal Amin Jaradat, Petrushova L. A., Mospanova E. V., Savchenkova L. V., Kuz'min V. E., Lyahovsky A. V. 4-Hydroxyquinolin-2-ones and their Close Structural Analogues as a New Source of Highly Effective Pain-killers. In book: Pain and Treatment, Racz G.B. and Noe C.E. (Ed.), Rijeka: InTech, 2014, pp.21-73. DOI: 10.5772/57402.

17. Ukrainets I. V., Petrushova L. A., Dzyubenko S. P., Sim G. Chemistry of Heterocyclic Compounds, 2014, Vol. 50, No.1, pp.103-110. doi:10.1007/s10593014-1452-0.

18. Ukrainets I. V., Petrushova L. A., Dzyubenko S. P., Liu Yangyang. Chemistry of Heterocyclic Compounds, 2014, Vol. 50, No.4, pp.564-572. DOI:10.1007/ s10593-014-1508-1.

19. Ukrainets I. V., Alexeeva T. V., Davidenko A. A., Grinenko V. V. Zhurnal Organichnoi ta Farmatsevtichnoi Khimii - Journal of Organic and Pharmaceutical Chemistry, 2015, Vol. 13, No.3(51), pp.9-14.

20. Ukrainets I. V., Tugaibei I. A., Bereznyakova N. L., Kravchenko V. N., Turov A. V. Chemistry of Heterocyclic Compounds, 2008, Vol. 44, No.5, pp.565-575. DOI: 10.1007/s10593-008-0076-7.

21. Potapov V. M. Stereokhimiya (Stereochemistry). Moscow, Khimiya, 1988, 464 p.

22. Günther H. NMR Spectroscopy: Basic Principles, Concepts, and Applications in Chemistry. Weinheim, Wiley-VCH, 2013, 734 .

23. Ukrainets I. V., Taran S. G., Likhanova N. V., Rybakov V. B., Gorokhova O. V., Jaradat Nidal Amin. Chemistry of Heterocyclic Compounds, 2000, Vol. 36, No.1, pp.49-56. DOI: 10.1007/BF02256844.

24. Vogel H. G. Drug Discovery and Evaluation: Pharmacological Assays. Berlin, Springer; 2008, pp.1030-1032.

25. Sigidin Ya. A., Shvarts G. Ya., Arzamastsev A. P., Liberman S. S. Lekarstvennaya terapiya vospalitel'nogo protsessa (Drug Therapy of the Anti-inflammatory Process). Moscow, Meditsina; 1988, pp.60-63.

26. Sernov L. N., Gatsura V. V. Elementy experimentalnoi pharmakologii (Elements of Experimental Pharmacology). Moscow, Nauka, 2000, pp.308-316.

Надійшла до редакції 07.09.2015 р. 